\title{
MOTIVATING FACTORS FOR PRIVATE CAR USERS TO USE PUBLIC TRANSPORT
}

\author{
Md. Asif Hasan Anik ${ }^{1}$, Fuad Ahmed ${ }^{2}$, Fahmun Nabi Atin ${ }^{3}$, Nuzhat Tabassum Ahmed ${ }^{4}$, \\ Amit Mutsuddy ${ }^{5}$, Musaddik Al Imran ${ }^{6}$, Nazia Haque ${ }^{7}$, Tasman Zihan ${ }^{8}$, Rafiz Rayhan ${ }^{9}$ \\ ${ }^{1}$ Department of Civil and Environmental Engineering, Islamic University of Technology, Dhaka, Bangladesh \\ 2,3,4,5,6,7,8,9 Institute of Business Administration, University of Dhaka, Dhaka, Bangladesh
}

Received 10 October 2017; accepted 25 December 2017

\begin{abstract}
Urban areas all over the world are becoming private car-dominated and less sustainable day by day. In order to limit the growth of private cars and to efficiently attract the commuters from private car to public transit, this paper aimed to identify the factors motivating the commuters to use public transport and to find out the attributes of public transport which need urgent improvement. The research was based on a survey of private car users of Dhaka city covering perceptions of public transit service performance, private car users urge to switch to public transport, the relationship between the motivating factors and the socio demographic characteristics of the respondents. The findings of this study indicated that both males and females have a negative attitude towards the public transportation system of the city. The analysis showed that the private car users will be encouraged to switch to public transport if they get facilities like air conditioning system, seat availability, women bus service, clean and comfortable bus etc. The results also showed that majority of the private car users having higher secondary and undergraduate degrees think that people use private car to highlight their social status while the respondents having postgraduate education has a mixed opinion in this regard. The findings of this study will definitely assist the transport policy makers to incorporate the necessities of private car users as public input in the transport planning process.
\end{abstract}

Keywords: private car, public transport, motivating factors, sustainable transportation.

\section{Introduction}

With traffic congestion rapid increase in urban areas, considering how to switch private car users to public transit has become paramount (Ory et al., 2004). Private car use has grown rapidly during the last decades. The number of motorized vehicles in the world grew from about 75 million to about 675 million between 1950 and 1990. The increasing car use has created various environmental, social and economic problems. Environmental problems concern the emissions of toxic and harmful substances, which, among other things, contribute to global warming, smog and acid precipitation. . Moreover, less space is available for walking and cycling especially in urban areas. Whereas more and more people own a car, those without access to cars become more disadvantaged and socially isolated as workplaces, shops

${ }^{1}$ Corresponding author: asifhasananik@iut-dhaka.edu 
and leisure facilities relocate to suit car users (Steg, 2003).

The concept of sustainable transportation system of a city expects most trips being made by walking, bicycle or public transport in a safe, secured, convenient, affordable and timely manner with leaving very few trips for car (Anik et al., 2017). In many countries, major investments are being made in public transport systems in order to make them more competitive with other means of transport, most notably private cars. New services are being developed and old ones are being improved. However, an increase in supply (qualitatively or quantitatively) will not automatically lead to a corresponding increase in demand and satisfaction (Fujii and Kitamura, 2003; Mackett and Edwards, 1998). To make sure that investment really attracts the existing and potential users, knowledge about user satisfaction should provide policymakers with valuable information. In particular, satisfaction studies can provide decision makers with information about what customers consider important, as well as information about how the existing public transport service is perceived as performing in these dimensions (Friman and Fellesson, 2009).

Transport service performance could be evaluated by many attributes, for example, accessibility, reliability, frequency, travel time, cost, comfort level, security, network coverage and cleanliness (Hensher et al., 2003; Ohnmacht and Scherer 2010; Tyrinopoulos and Antoniou, 2008). Among these attributes, reliability, cost, convenience and travel time are the most important (Stradling et al., 2000; Kingham et al., 2001). In terms of private car, many studies suggest that monetary costs, freedom, travel time, comfort, availability and reliability are its main evaluation attributes. In addition, cost and travel time are deemed as the most important attributes (Gärling et al., 2002; Steg et al., 2002; Li et al., 2010; Hagman, 2003). However, it is not practical for transit to simultaneously improve all attributes which are not good enough, especially when funds are limited or travelers do not think this attribute is important. Hence, it is a question what attributes need urgently to be improved if transit agencies intend to let travelers switch private car to public transit (Wang et al., 2013).

This research, on the use of public transport, is focused on identifying the factors that will influence private car users to use the public form of transit around a city. Additionally, this study concentrates on examining the challenges faced by the city dwellers when commuting by public transport and to gather insights on the road user priorities. The specific objectives of the study are divided into three parts: a) to examine the attitude of private car users towards the public transport system of the city and the factors that will motivate them to use public transport; b) to check whether the perception of private car users varies with education, gender and occupation; c) to check whether people use private car to highlight their social status. The scope or extent of this research portrays precisely the area covered by the report. The main focus area is the transportation system of Dhaka, the capital of Bangladesh. The transportation system includes public transportation, private transportation and also mass transportation. In this study, total of 164 private car users participated in the online questionnaire survey to provide their feedbacks expressing their attitude towards the public transportation system of the city. After analysing their responses significant conclusion are drawn and discussed. The results of this study will 
certainly assist the transportation planners and policy makers with more knowledge regarding the priorities and satisfaction of the transport users of the city.

\section{Study Area}

This manuscript selects Dhaka, the capital of Bangladesh as its study area. Dhaka, one of the most populated cities in the world has a population of over 18 million as of 2016. Dhaka city is one of the most densely populated areas in the world, with a density of 23,234 people per square kilometer within a total area of 300 square kilometer (World population, 2017). The city is like a miniature world that represents the entire country, it is the economic, political and cultural center of Bangladesh. Being a thriving, colorful and congested metropolis, one of the biggest problems of living in Dhaka city is the traffic congestion.

The transportation system of Dhaka is predominantly road based where nonmotorized transportation (mainly rickshaws) has a substantial share. Traffic in Dhaka is known for its heterogeneity due to the wide variation in the operation and performance characteristics of vehicles (motorized, nonmotorized, slow moving, fast-moving) that causes severe congestion and pollution especially in road intersection (Karim et al., 1998). Dhaka's road network is nearly 3000 $\mathrm{km}$ of which $200 \mathrm{~km}$ are primary, $110 \mathrm{~km}$ are secondary, 50 are $\mathrm{km}$ feeder and $2640 \mathrm{~km}$ are narrow roads which represents only $7 \%$ of its built-up area where standard condition requires at least $25 \%$ of the city area should be allocated for roads. The primary mode of transport is rickshaw (34\%), almost half (44\%) the trips use transit/buses; and a quarter (22\%) comprise of walking (14\%) and other nontransit motorized (8\%) modes. Current average trip length is $5.37 \mathrm{~km}$ (by buses $8.40 \mathrm{~km}$; by rickshaws $2.34 \mathrm{~km}$ ) and across all modes of travel average trip time is about 15 minutes (Strategic Transport Plan for Dhaka, 2005). Although driving a car can be a nerve wrecking experience in Dhaka, private cars are one of the most common vehicles in the country. Out of about total 21 million trips generated in Dhaka city area every day, only $5 \%$ are carried out by private cars, which however cover roughly $80 \%$ of the road space and are the main cause of traffic congestion. Yet $28 \%$ of the total trips are carried out by buses which only use about $5 \%$ of the road space whereas $58 \%$ of the total trips are made by walking, bicycling, or riding on rickshaws, also called non-motorized transport modes (NMT). These NMT modes barely get proper allocation of road space. There are no dedicated bicycle or rickshaw lane on any roads in Dhaka and less than $25 \%$ of roads have separated, paved sidewalks, most of which are either occupied by parked cars, hawkers or damaged without proper maintenance (Fang, 2014).

Traffic congestion has been obstructing trade and commerce in Dhaka city. The residents of the city undergo physical stress due to the traffic system which is one of the most chaotic ones in the world. Trucks, buses, cars are illegally parked everywhere, faulty traffic signaling systems, inadequate manpower, narrow road spaces and vehicles viciously overtaking one another create intense prolonged traffic. Traffic congestion in the capital eats up around 2425 million US dollar per year and some 3.2 million business hours every day (RSTP, 2016). Today, the average traffic speed in Dhaka is 6.4 kilometer per hour (kph) and if vehicle growth continues at its current pace, without substantial public transport investment, the average speed may fall to $4.7 \mathrm{kph}$ by 2035 - about as slow as walking (Lomborg, 2016). 
In Dhaka, the public transport system is age old and dilapidated. It has been seen that over $95 \%$ of the buses plying on different routes of the city do not comply with the requirements mentioned in the Motor Vehicles Act (MVA), most don't have back lights, indicators, etc. (Litan, 2017). A large majority of the public transport here are unfit both environmentally and mechanically, adversely affecting the city's ecological environment and being highly susceptible to accidents. Shortages of terminals and bus stops, the absence of separate lanes for buses, and the extreme lack of discipline in how and where buses stop on the thoroughfares create additional problems for traffic movement (Andaleeb et al., 2007). The economic, physical and mental sufferings of the city dwellers make it the most pressing issue that needs to be solved. To reduce traffic congestion it is necessary to reduce the number of vehicles that are being driven on the road, the public transport system has to be improved, curtail the number of private cars in the city and motivate more people to use the public transport.

\section{Methodology}

This study used an online survey questionnaire to interview the private car users. Sampling size is deemed to include adequate number of respondents. Probability sampling, especially stratified sampling method is considered to be the first sampling technique for this research followed by the Quota sampling. Data for this research is collected from primary sources and also from secondary sources. Secondary data source includes literature review and content analysis, research papers on public transit system of Dhaka city. The data collection mainly focus on identifying the standard facilities that would motivate the private transport users to use public transport.
At the initial phase of the survey, respondents are chosen using the Stratified Sampling Technique. At the second stage, Quota sampling method is applied to get a better idea of the private transport users' opinions in terms of their income level. The respondents are divided into three groups based on their income and information is collected through Quota sampling. In statistics, stratified sampling is a method of sampling from a population. Stratification is the process of dividing members of the population into homogeneous subgroups before sampling. The strata should be mutually exclusive: every element in the population must be assigned to only one stratum. The strata should also be collectively exhaustive: no population element can be excluded. Then simple random sampling or systematic sampling is applied within each stratum. This improves the representativeness of the sample by reducing sampling error. It can produce a weighted mean that has less variability than the arithmetic mean of a simple random sample of the population. Quota sampling is a nonprobability sampling technique wherein the assembled sample has the same proportions of individuals as the entire population with respect to known characteristics, traits or focused phenomenon.

In the first part of the questionnaire the respondents are asked about their socio demographic information. Likert scale is used for the second section of the questionnaire. In this part respondents are asked to indicate their opinions by checking how strongly they disagree or agree with constructed statements that range from strongly disagree to strongly agree. Respondents are asked to pick any one of the five alternatives- strongly disagree, disagree, indifferent, agree, and strongly agree. They have a value ranging from 1 to 5 with 3 as neutral value. 
Before the final questionnaire is given to the respondents, pilot test is conducted in order to find out whether the questions are clear. For this, few respondents are chosen and made to take the surveys. Around 7-8 pretesting are done from different age groups and occupation level. The ambiguity that came up is corrected and then the final questionnaire is set. The purpose of the research is mentioned in the beginning of the survey in order to get crude results. The questionnaire is prepared in English. The questionnaire has three distinctive parts:

- Part 1: Identification Data: This part addresses the names and contact information of the respondents. The purpose is to get the complete contact information of the respondents so that they can be traced back in case of any confusion/ further information;

- Part 2: LikertScale: There are twenty-four statements in this part. Respondents are expected to rate the statements based on their perception. This part aims to know the respondents' perception of the transport system of the city;

- Part 3: Classification Data: Personal data such as gender, age, occupation, and education level of the respondents are collected through this part.

After collecting the responses, the data are aggregated by calculating their mean, standard deviation, skewness and kurtosis using Statistical Package for the Social
Sciences (SPSS), a software package used for logical batched and non-batched statistical analysis followed by a hypothesis testing to determine whether the attitude towards public transport differ with gender. A ChiSquare Test is run to test which of the variables in the questionnaire are associated with education level, occupation and gender. Finally a correlation matrix is developed with the age of the respondents and the top correlations are shown. The association between these variables are measured by Chi-Square Test. For understanding the correlation between the variables and perception, Correlation Test is done.

\section{Results and Discussion}

This part of the paper contains the reliability analysis of the data used in this study and the results obtained from the statistical analysis. It also contains significant discussions on the overall results obtained.

\subsection{Reliability of the Data}

The reliability of the data was verified using the Cronbach's Alpha Technique. Cronbach's Alpha is a measure of internal consistency, that is, how closely related a set of items are as a group. It is considered to be a measure of scale reliability (UCLA: Statistical Consulting Group, 2006). The data was found to be 0.871 which is shown in Table 1.

\section{Table 1}

Reliability Statistics

\begin{tabular}{|c|c|}
\hline \multicolumn{2}{|c|}{ Reliability Statistics } \\
\hline Cronbach's Alpha & N of Items \\
\hline 0.871 & 24 \\
\hline
\end{tabular}


A Cronbach's Alpha of 0.70 and above is considered to be reliable (Lance et al., 2006; Nunnally, 1978). Our Cronbach's Alpha based on standardized items was 0.871 , signifying the reliability of data.

\subsection{Condition of Public Transport}

The complex variable "Condition of public transport" had a mean of 1.772 with a standard deviation of 0.6546 , indicating that private transport users have a negative perception towards the present conditions of public transportation service in Dhaka city. The variable was positively skewed. It had a skewness of 1.1716 which shows disagreement with the factors under this variable.

The statement 'It is safe to use public transport' had a mean of 2.41, 'The existing public bus drivers are adequately capable and efficient to drive the vehicles' had 1.79, 'The current state of public transportation is good enough for the use of people from all walks of life' had 1.52 and 'Existing buses in the city go through proper scheduled maintenance checkups' had 1.46. As a result the distribution was very steep with a positive kurtosis value of 0.8454 , concentrating the variable mostly on the disagreement side. It was seen that the mean value in most cases although did not differ significantly from the test value but always leaned towards the disagreement side. The mean in each case is reasonably lower than 3 and thus demonstrated a negative attitude towards the conditions of public transport service in Dhaka city. The analysis of responses for condition of public transport are shown in Table 2.

Table 2

Analysis of Responses for Conditions of Public Transport

\begin{tabular}{|c|c|c|c|c|c|c|}
\hline No. & Statement & Mean & $\begin{array}{c}\text { Standard } \\
\text { Deviation }\end{array}$ & Skewness & Kurtosis & $\begin{array}{c}\text { Test Value=3 } \\
\text { (Significance } \\
\text { 2-tailed) }\end{array}$ \\
\hline & Condition of public transport & 1.772 & 0.9187 & 1.1716 & 0.8454 & 0.000 \\
\hline 1 & Seats are always available & 1.68 & 0.69 & 0.965 & 1.397 & 0.000 \\
\hline 2 & It is safe to use public transport & 2.41 & 0.996 & 0.145 & -1.015 & 0.000 \\
\hline 3 & $\begin{array}{c}\text { The existing public bus drivers are } \\
\text { adequately capable and efficient to } \\
\text { drive the vehicles }\end{array}$ & 1.79 & 0.962 & 1.222 & 0.953 & 0.000 \\
\hline 5 & $\begin{array}{c}\text { The current state of public } \\
\text { transportation is good enough for } \\
\text { the use of people from all walks } \\
\text { of life }\end{array}$ & 1.52 & 0.755 & 1.668 & 3.279 & 0.000 \\
\hline $\begin{array}{c}\text { Existing buses in the city go through } \\
\text { proper scheduled maintenance } \\
\text { check ups }\end{array}$ & 1.46 & 0.832 & 2.384 & 6.273 & 0.000 \\
\hline
\end{tabular}

\subsection{Development of Public Transport Service}

The complex variable "Development of public transport service" had a mean of
3.8425 with a standard deviation of 1.2004 , indicating that private transport users have a fairly positive perception towards the need of development of public transport service in the city. The variable was negatively 
skewed, had a skewness of -1.055 which shows agreement with the factors under this variable. For example 'Cleanliness of buses is a factor for its users' had a mean of
4.12 which shows a very high agreement to the statement. The analysis of responses for development of public transport service is shown in Table 3.

\section{Table 3}

Analysis of Responses for Development of Public Transport Service

\begin{tabular}{|c|c|c|c|c|c|c|}
\hline No. & Statement & Mean & $\begin{array}{l}\text { Standard } \\
\text { Deviation }\end{array}$ & Skewness & Kurtosis & $\begin{array}{c}\text { Test Value }=3 \\
\text { (Significance } \\
\text { 2-tailed) }\end{array}$ \\
\hline & $\begin{array}{l}\text { Development of public transport } \\
\text { service }\end{array}$ & 3.8407 & 1.2226 & -1.055 & .1867 & 0.002 \\
\hline 1 & $\begin{array}{c}\text { Cost of the ride is a prime motivator } \\
\text { for public transport usage }\end{array}$ & 3.26 & 1.341 & -0.402 & -1.074 & 0.016 \\
\hline 2 & $\begin{array}{l}\text { Availability of air conditioning } \\
\text { would encourage more people to } \\
\text { use public transport }\end{array}$ & 3.95 & 1.298 & -1.261 & 0.455 & 0.000 \\
\hline 3 & $\begin{array}{l}\text { Cleanliness of buses is a factor for } \\
\text { its users }\end{array}$ & 4.12 & 1.159 & -1.475 & 1.404 & 0.000 \\
\hline 4 & $\begin{array}{l}\text { Strict ticketing and queuing policies } \\
\text { would encourage people to use mass } \\
\text { transport }\end{array}$ & 3.85 & 1.170 & -1.141 & 0.584 & 0.000 \\
\hline 5 & $\begin{array}{l}\text { More sitting service buses in the } \\
\text { city would encourage people to use } \\
\text { buses more often }\end{array}$ & 3.87 & 1.120 & -1.045 & 0.468 & 0.000 \\
\hline 6 & $\begin{array}{l}\text { Women would be encouraged to } \\
\text { use public buses more if there were } \\
\text { more buses only for women }\end{array}$ & 3.93 & 1.201 & -1.127 & 0.482 & 0.000 \\
\hline 7 & $\begin{array}{l}\text { Reserved seats for women, senior } \\
\text { citizens and differently abled people } \\
\text { in mass transport would encourage } \\
\text { these people to use mass transport } \\
\text { more often }\end{array}$ & 3.84 & 1.091 & -1.260 & 1.217 & 0.000 \\
\hline 8 & $\begin{array}{l}\text { Fitness levels of buses is a concern } \\
\text { for its users }\end{array}$ & 3.92 & 1.223 & -1.068 & 0.194 & 0.000 \\
\hline
\end{tabular}

'Cost of the ride is a prime motivator for public transport usage' (3.26), 'Availability of air conditioning would encourage more people to use public transport' (3.95), 'Strict ticketing and queuing policies would encourage people to use mass transport' (3.85), 'More sitting services buses in the city would encourage people to use bus more often' (3.87), 'Women would be encouraged to use public bus more if there were more buses only for women' (3.93), 'Reserved seats for women, senior citizens and differently abled people in mass transport would encourage these people to use mass transport more often' (3.84), and 'Fitness level of buses is a concern for its users' (3.92). As a result the distribution was fairly steep with a mildly positive kurtosis value of 0.1867 which focus on the variables mostly on the positive side. It was seen that the mean value in most cases although do not differ significantly from the test value but always leaned towards the agreement side. The mean in each case was reasonably higher 
than 3 and thus demonstrated a positive attitude towards the need for development in the public transportations service in Dhaka, in order to boost their usage.

\subsection{Attitude towards Public Transport Service}

The complex variable "Attitude towards public transport service" had a mean of 2.264 with a standard deviation of 1.311 , indicating that private transport users have a negative attitude towards the public transportation services in Dhaka city. The variable was positively skewed, had a skewness of 0.6636 which shows disagreement with the factors under this variable. For example 'It is comfortable to use public transport' had a mean of 1.66 which shows a high disagreement to the statement.
The analysis of responses for attitude towards public transport is shown in Table 4.

'You always reach your destination on time while travelling via public transport' (1.97), 'It is convenient to use public transport' (2.30). 'It is easy to get on a public transport' (2.07). 'Highlighting social status is a motivator for private car users to use their cars' (3.32). As a result the distribution was steep with a negative kurtosis value of -0.7639 which focuses the variables mostly on the negative side. It was seen that the mean value in most of the cases leaned towards the disagreement side. The mean in almost each case was reasonably lower than 3 and thus demonstrated a negative attitude towards the public transportations service in Dhaka, in order to boost their usage.

Table 4

Analysis of Responses for Attitude towards Public Transports

\begin{tabular}{|c|c|c|c|c|c|c|}
\hline No. & Statement & Mean & $\begin{array}{l}\text { Standard } \\
\text { Deviation }\end{array}$ & Skewness & Kurtosis & $\begin{array}{c}\text { Test Value }=3 \\
\text { (Significance } \\
\text { 2-tailed) }\end{array}$ \\
\hline & $\begin{array}{l}\text { Attitude Towards Public Transport } \\
\text { Services }\end{array}$ & 2.264 & 1.311 & 0.6636 & -0.7639 & 0.000 \\
\hline 1 & $\begin{array}{c}\text { You always reach your destination } \\
\text { on time while travelling via public } \\
\text { transport }\end{array}$ & 1.97 & 0.832 & 0.769 & 0.623 & 0.000 \\
\hline 2 & $\begin{array}{l}\text { It is comfortable to use public } \\
\text { transport }\end{array}$ & 1.66 & 0.832 & 1.295 & 1.549 & 0.000 \\
\hline 3 & $\begin{array}{l}\text { It is convenient to use public } \\
\text { transport }\end{array}$ & 2.30 & 1.103 & 0.605 & -0.593 & 0.000 \\
\hline 4 & $\begin{array}{l}\text { It is easy to get on a public } \\
\text { transport }\end{array}$ & 2.07 & 1.063 & 0.888 & -0.058 & 0.000 \\
\hline 5 & $\begin{array}{l}\text { Highlighting social status is a } \\
\text { motivator for private car users to } \\
\text { use their cars }\end{array}$ & 3.32 & 1.212 & -0.38 & -0.839 & 0.001 \\
\hline
\end{tabular}

\subsection{More Routes of Public Transport Service}

The complex variable "More routes of public transport service" had a mean of 3.93 with a standard deviation of 1.108 , indicating that private transport users have a fairly positive perception towards the routes of public transportation service in Dhaka city. The variable was negatively skewed, had a skewness of -1.232 which shows agreement with the factors under this variable. 
'The route that a bus takes is an essential factor for a commuter' (3.85), 'If buses only stopped at designated stoppages, then it would encourage more people to use public buses' (4.01). As a result the distribution was fairly steep with a positive kurtosis value of 1.062 which focuses the variables mostly on the positive side. It was seen that the mean value in most cases although did not differ significantly from the test value but always leaned towards the agreement side. The mean in each case was reasonably higher than 3 and thus demonstrated a positive attitude towards the need for more routes in the public transportations service in Dhaka, in order to boost their usage. The results are shown in Table 5.

\section{Table 5}

Analysis of Responses for Routes of Public Transport Services

\begin{tabular}{|c|c|c|c|c|c|c|}
\hline No. & Statement & Mean & $\begin{array}{c}\text { Standard } \\
\text { Deviation }\end{array}$ & Skewness & Kurtosis & $\begin{array}{c}\text { Test Value=3 } \\
\text { (Significance } \\
\text { 2-tailed) }\end{array}$ \\
\hline & $\begin{array}{c}\text { More routes of Public Transport } \\
\text { Services }\end{array}$ & 3.93 & 1.108 & -1.232 & 1.062 & 0.000 \\
\hline 1 & $\begin{array}{c}\text { The route that a bus takes is an } \\
\text { essential factor for a commuter }\end{array}$ & 3.85 & 1.089 & -1.223 & 1.199 & 0.000 \\
\hline 2 & $\begin{array}{c}\text { If buses only stopped at designated } \\
\text { stoppages, then it would encourage } \\
\text { more people to use public buses }\end{array}$ & 4.01 & 1.124 & -1.283 & 1.074 & 0.000 \\
\hline
\end{tabular}

\subsection{Alternatives of Public Transport Service}

The complex variable "Alternatives of public transport service" had a mean of 3.96 with a standard deviation of 1.162 , indicating that private transport users have a fairly positive perception towards the need of alternatives of public transportation services in Dhaka city. The variable was negatively skewed, had a skewness of -1.209 which shows agreement with the factors under this variable. For example 'An increased number of intercity train would motivate people to use trains regularly' had a mean of 4.12 which shows a very high agreement to the statement. The results are shown in Table 6.
'Following schedule for trains running within the city would encourage more people to use trains' (4.00), 'Introduction of water taxies would encourage people to use them in areas which are accessible to water bodies' (3.75). As a result the distribution was fairly steep with a positive kurtosis value of 0.752 which focuses the variables mostly on the positive side. It was seen that the mean value in most cases although did not differ significantly from the test value but always leaned towards the agreement side. The mean in each case was reasonably higher than 3 and thus demonstrated a positive attitude towards the need for alternatives in the public transportations services in Dhaka. 


\section{Table 6}

Analysis of Responses for Alternatives of Public Bus Services

\begin{tabular}{|c|c|c|c|c|c|c|}
\hline No. & Statement & Mean & $\begin{array}{c}\text { Standard } \\
\text { Deviation }\end{array}$ & Skewness & Kurtosis & $\begin{array}{c}\text { Test Value=3 } \\
\text { (Significance } \\
\text { 2-tailed) }\end{array}$ \\
\hline 1 & Alternatives of Public Bus Services & 3.96 & 1.162 & -1.209 & 0.752 & 0.000 \\
\hline 2 & $\begin{array}{c}\text { Following schedule for trains } \\
\text { running within the city would } \\
\text { encourage more people to use trains }\end{array}$ & 4.00 & 1.119 & -1.278 & 1.089 & 0.000 \\
\hline $\begin{array}{c}\text { An increased number of intercity } \\
\text { train would motivate people to use } \\
\text { trains regularly }\end{array}$ & 4.12 & 1.132 & -1.541 & 1.835 & 0.000 \\
\hline & $\begin{array}{c}\text { Introduction of water taxies would } \\
\text { encourage people to use them in } \\
\text { areas which are accessible to water } \\
\text { bodies }\end{array}$ & 3.75 & 1.210 & -0.895 & 0.004 & 0.000 \\
\hline
\end{tabular}

\subsection{Private Car Users' Opinion on Public Transports Services with Respect to Gender}

Since gender is distinctly divided into male and female, they were considered as separate population.

Here, the null hypothesis, $\mathrm{H}_{\mathrm{O}}: \mu_{1}=\mu_{2}$ (the mean of two population is equal).

And the alternate hypothesis, $\mathrm{H}_{\mathrm{A}}: \mu_{1} \neq \mu_{2}$ (the mean of two population is different).
Here the $5 \%$ level of significance had been considered for hypotheses testing. It was also assumed that both of the population has equal variance.

If the level of significance is greater than 0.05 , the null hypotheses are rejected and alternate hypotheses are accepted which indicates that the mean of the population is different. Table 7 and Table 8 show the results:

\section{Table 7}

Analysis of Attitude towards Public Transport with Respect to Gender

\begin{tabular}{|c|c|c|c|c|c|c|}
\hline $\begin{array}{l}\text { Complex } \\
\text { Variable }\end{array}$ & $\begin{array}{c}\text { Simple } \\
\text { Variable }\end{array}$ & & $\mathbf{N}$ & Mean & $\begin{array}{l}\text { Standard } \\
\text { Deviation }\end{array}$ & $\begin{array}{c}\text { Sig. } \\
\text { (2 tailed) }\end{array}$ \\
\hline \multirow{10}{*}{$\begin{array}{c}\text { Attitude } \\
\text { Towards Public } \\
\text { Transports }\end{array}$} & \multirow{2}{*}{$\begin{array}{c}\text { Reaching } \\
\text { Timely }\end{array}$} & Male & 130 & 1.98 & .867 & \multirow{2}{*}{.824} \\
\hline & & Female & 34 & 1.94 & .694 & \\
\hline & \multirow{2}{*}{ Comfort Level } & Male & 130 & 1.64 & .797 & \multirow{2}{*}{.547} \\
\hline & & Female & 34 & 1.74 & .963 & \\
\hline & \multirow{2}{*}{ Convenience } & Male & 130 & 2.28 & 1.114 & \multirow{2}{*}{.621} \\
\hline & & Female & 34 & 2.38 & 1.074 & \\
\hline & \multirow{2}{*}{ Easiness } & Male & 130 & 2.05 & 1.044 & \multirow{2}{*}{.756} \\
\hline & & Female & 34 & 2.12 & 1.149 & \\
\hline & \multirow{2}{*}{ Social Status } & Male & 130 & 3.36 & 1.251 & \multirow{2}{*}{.360} \\
\hline & & Female & 34 & 3.15 & 1.048 & \\
\hline
\end{tabular}


For the complex variable attitude towards public transports, private car users' perception of public transport services with respect to gender is measured and mean values of female and male has been compared. From Table X, it can be deduced that:

- Mean values of two genders were not significantly different when "Private car users reach their destination in time when they get on a public transport" was hypothesized;

- Mean values of two genders were not significantly different when "It is comfortable to use public transport" is hypothesized. Interestingly, Males disagree more to the statement than the females do in this regard;

- Mean values of two genders were not significantly different when "It is convenient to use public transport" is hypothesized. Again in this case, males disagree more to the statement than the females do in this regard;

- Mean values of two genders were not significantly different when "It is easy to use public transport" is hypothesized;

- Mean values of two genders were not significantly different when "People use private car to highlight their social status" is hypothesized. However, males agree more to the statement than the females do in this regard.

\section{Table 8}

Analysis of Development of Public Transport Services with Respect to Gender

\begin{tabular}{|c|c|c|c|c|c|c|}
\hline $\begin{array}{l}\text { Complex } \\
\text { Variable }\end{array}$ & $\begin{array}{c}\text { Simple } \\
\text { Variable }\end{array}$ & & $\mathbf{N}$ & Mean & $\begin{array}{l}\text { Standard } \\
\text { Deviation }\end{array}$ & $\begin{array}{c}\text { Sig. } \\
\text { (2-tailed) }\end{array}$ \\
\hline \multirow{16}{*}{$\begin{array}{c}\text { Developments } \\
\text { of Public } \\
\text { Transport } \\
\text { Services }\end{array}$} & \multirow{2}{*}{$\begin{array}{l}\text { Cost of the } \\
\text { Ride }\end{array}$} & Male & 130 & 3.20 & 1.411 & \multirow{2}{*}{.296} \\
\hline & & Female & 34 & 3.47 & 1.022 & \\
\hline & \multirow{2}{*}{$\begin{array}{c}\text { Availability } \\
\text { of AC }\end{array}$} & Male & 130 & 3.95 & 1.325 & \multirow{2}{*}{.984} \\
\hline & & Female & 34 & 3.94 & 1.205 & \\
\hline & \multirow{2}{*}{ Hygiene } & Male & 130 & 4.11 & 1.196 & \multirow{2}{*}{.861} \\
\hline & & Female & 34 & 4.15 & 1.019 & \\
\hline & \multirow{2}{*}{ Ticketing } & Male & 130 & 3.88 & 1.201 & \multirow{2}{*}{.531} \\
\hline & & Female & 34 & 3.74 & 1.053 & \\
\hline & \multirow{2}{*}{$\begin{array}{l}\text { Sitting Service } \\
\text { Bus }\end{array}$} & Male & 130 & 3.85 & 1.149 & \multirow{2}{*}{.687} \\
\hline & & Female & 34 & 3.94 & 1.013 & \\
\hline & \multirow{2}{*}{ Women Bus } & Male & 130 & 3.90 & 1.206 & \multirow{2}{*}{.577} \\
\hline & & Female & 34 & 4.03 & 1.193 & \\
\hline & \multirow{2}{*}{$\begin{array}{c}\text { Seat } \\
\text { Reservation }\end{array}$} & Male & 130 & 3.85 & 1.103 & \multirow{2}{*}{.915} \\
\hline & & Female & 34 & 3.82 & 1.058 & \\
\hline & \multirow{2}{*}{ Fitness } & Male & 130 & 3.94 & 1.262 & \multirow{2}{*}{.718} \\
\hline & & Female & 34 & 3.85 & 1.077 & \\
\hline
\end{tabular}


For the complex variable Interactional Fairness, perception of fairness and ethics with respect to gender has been measured and mean values of female and male has been compared. From Table X, it can be deduced that:

- Mean values of two genders were not significantly different when "Cost of the ride is a prime motivator for public transport usage" is hypothesized. Females agree more to the statement than the males do in this regard;

- Mean values of two genders were not significantly different when "Availability of $\mathrm{AC}$ would encourage private car users to use public transports" is hypothesized. Both the males and the females fairly agreed to the statement;

- Mean values of two genders were not significantly different when "Cleanliness of public transport is a prime motivating factor for private car users" is hypothesized. Both the males and the females fairly agreed to the statement;

- Mean values of two genders were not significantly different when "Strict ticketing and queuing policies would encourage private car users to use public transport" is hypothesized. Males agree to the statement more than the females do in this regard;

- Mean values of two genders were not significantly different when "Sitting service buses would encourage private car users to use public transport" is hypothesized;

- Mean values of two genders were not significantly different when "A large number of women buses would encourage the women to use public transport" is hypothesized. Women agree more to the statement than the males do in this regard;

- Mean values of two genders were not significantly different when "Reserved Seats for women, senior citizens and differently abled people in mass transport would encourage these people to use mass transport more often" was hypothesized;

- Mean values of two genders were not significantly different when "Fitness level of public transports is a concern for private car users" is hypothesized. Males agree more to the statement than the females do in this regard.

From the analysis of independent sample T-Test it can said that private car users' perception of public transport service did not vary across gender. The top 5 demands/ facilities private car users (both the males and the females) seek in a public transport are:

- Hygiene;

- Availability of Air Conditioned transport;

- Women bus service;

- Proper fitness level of transport;

- More sitting service bus.

\subsection{Association of the Variables with Education Level, Occupation and Gender}

A Chi-Square test was run to test whether any of the variables was associated with education level or occupation or gender. The results are shown in Table 9. 
Table 9

Chi-Square Analysis of the Variables

\begin{tabular}{|c|c|c|c|}
\hline \multirow{2}{*}{ Variables } & \multicolumn{3}{|c|}{ Significance Value } \\
\hline & Gender & Occupation & Education Level \\
\hline Cost of the Ride & .048 & .155 & .061 \\
\hline Reaching Timely & .545 & .919 & .097 \\
\hline Seats Availability & .802 & .119 & .599 \\
\hline Comfort & .404 & .109 & .763 \\
\hline Safety & .243 & .987 & .691 \\
\hline Convenience & .595 & .780 & .678 \\
\hline Easiness & .444 & .642 & .944 \\
\hline $\mathrm{AC}$ & .313 & .939 & .637 \\
\hline Social Status & .172 & .034 & .037 \\
\hline Bus Route & .334 & .372 & .276 \\
\hline Bus-Stoppage & .168 & .093 & .236 \\
\hline Hygiene & .368 & .193 & .239 \\
\hline Driver's Ability & .916 & .043 & .013 \\
\hline Current State & .004 & .138 & .089 \\
\hline Ticketing & .394 & .968 & .680 \\
\hline Sitting Service Buses & .343 & .841 & .976 \\
\hline Mass-use & .215 & .619 & .561 \\
\hline Women Bus & .443 & .086 & .417 \\
\hline Reserved Seats & .969 & .891 & .461 \\
\hline Fitness level & .186 & .732 & .617 \\
\hline Maintenance & .079 & .369 & .664 \\
\hline Scheduled Trains & .160 & .620 & .684 \\
\hline More Trains & .106 & .389 & .584 \\
\hline Water Taxies & .012 & .607 & .895 \\
\hline
\end{tabular}

From the chi-square analysis, it can be deduced that:

- Gender was associated with cost of the ride, current state, maintenance and water taxies;

- Occupation was associated with social status and driver's ability;

- Education level as associated with social status and driver's ability.
4.9. Private Car Users' Perception of Highlighting Their Social Status with Respect to Their Education Level

Table 10 shows the analysis results of the variable 'Social Status' with respect to education level. 


\section{Table 10}

Analysis of the Variable 'Social Status' with Respect to Education Level

\begin{tabular}{|c|c|c|c|c|c|c|}
\hline \multirow[b]{2}{*}{ Education Level } & \multicolumn{5}{|c|}{ Social Status } & \multirow[b]{2}{*}{ Total } \\
\hline & $\begin{array}{l}\text { Strongly } \\
\text { Disagree }\end{array}$ & Disagree & Indifferent & Agree & $\begin{array}{c}\text { Strongly } \\
\text { Agree }\end{array}$ & \\
\hline HSC or Equivalent & $4.55 \%$ & $9.09 \%$ & $27.27 \%$ & $45.45 \%$ & $13.63 \%$ & $100 \%$ \\
\hline Undergraduate & $3.41 \%$ & $18.18 \%$ & $20.45 \%$ & $38.64 \%$ & $19.32 \%$ & $100 \%$ \\
\hline Masters \& Above & $20.37 \%$ & $22.22 \%$ & $18.52 \%$ & $25.93 \%$ & $12.96 \%$ & $100 \%$ \\
\hline
\end{tabular}

From the table, it can be deduced that:

- Majority of the private car users having HSC or equivalent level of education and undergraduate degrees responded positively to the statement "People use private cars to highlight their social status".

- The private car users having Masters or above level of education had a mixed opinion in this regard. Contrary to others, $42.59 \%$ of them disagreed to the statement.

\subsection{Private Car Users' Perception of Highlighting Their Social Status with Respect to Their Occupation}

Table 11 shows the analysis results of the variable 'Social Status' with respect to occupation.

Table 11

Analysis of the Variable 'Social Status' with Respect to Occupation

\begin{tabular}{|c|c|c|c|c|c|c|}
\hline \multirow[b]{2}{*}{ Occupation } & \multicolumn{5}{|c|}{ Social Status } & \multirow[b]{2}{*}{ Total } \\
\hline & $\begin{array}{l}\text { Strongly } \\
\text { Disagree }\end{array}$ & Disagree & Indifferent & Agree & $\begin{array}{c}\text { Strongly } \\
\text { Agree }\end{array}$ & \\
\hline Businessperson & $4.76 \%$ & $47.62 \%$ & $29.52 \%$ & $19.04 \%$ & $19.04 \%$ & $100 \%$ \\
\hline Govt. Service Holder & $14.29 \%$ & $28.57 \%$ & $28.57 \%$ & $28.57 \%$ & $0 \%$ & $100 \%$ \\
\hline $\begin{array}{c}\text { Private Service } \\
\text { Holder }\end{array}$ & $12.5 \%$ & $20.83 \%$ & $16.67 \%$ & $25 \%$ & $25 \%$ & $100 \%$ \\
\hline Student & $8.70 \%$ & $11.96 \%$ & $23.91 \%$ & $39.13 \%$ & $16.30 \%$ & $100 \%$ \\
\hline Others & $7.69 \%$ & $0 \%$ & $15.38 \%$ & $61.54 \%$ & $15.38 \%$ & $100 \%$ \\
\hline
\end{tabular}

From the table, it can be deduced that:

- Majority of the business person responded negatively to the statement "People use private cars to highlight their social status"

- Government service holders had a mixed opinion in this regard whereas $50 \%$ of the private service holders agreed to this statement;
- Private car users who are students and from other occupation groups responded fairly positively to the statement (55.43\% and $76.92 \%$ respectively).

\subsection{Correlation between Variables and Age of the Respondents}

A correlation matrix was developed with the age of the respondents.The top five correlations are as follows in Table 12. 
Table 12

Top 5 Correlations between the Variables and Age of the Respondents

\begin{tabular}{|c|c|}
\hline Variables & Correlation \\
\hline Cost-efficient Ride & -0.30582 \\
\hline Current State & -0.18263 \\
\hline Women Bus & -0.17995 \\
\hline Social Status & -0.17606 \\
\hline Bus Stoppage & -0.16505 \\
\hline
\end{tabular}

From the table it can be deduced that:

- All of the top five correlations were negative in value (Inverse relation);

- All of the top five correlations were weak in strength (considering $0-0.4=$ weak, $0.4-.7=$ moderate, and $.7-1=$ strong.

\section{Conclusion}

The objective of this research is accomplished through rigorous data collection and intricate methods of data analysis. After conducting the survey with 164 private car users in Dhaka city, based on the perception of the respondents it is possible to infer from the results that the private car users are not satisfied with the way public transportation sector of the city functions. In this study, on matters regarding current conditions of public transport, development of services and other criterions, parameters are set. Under these parameters hypotheses are established to reach a conclusion. The results of these hypotheses prove their negative attitude towards public transport and suggest some facilities that would encourage them to use public transport.

The verdict that can be reached through the data collected and analyzed for the purpose of this research is that, the private car users would be motivated to use public transport if they get facilities like -air conditioned bus, women bus service, reserved seats for women in the bus, facilities for senior citizens and differently-abled person, more sitting service bus, clean and comfortable bus, commuter train and water taxi service. Additionally, the results show that in most of the cases both males and females agree to their perception and negative attitude towards public transportation of the city. This study corroborate research showing that majority of the private car users having higher secondary or equivalent level of education and undergraduate degrees think that people use private car to highlight their social status but the car users having masters or above level of education has a mixed opinion in this regard. Majority of the business persons responded negatively to the statement that people use private car to highlight their social status where government service holders has a mixed opinion in this regard and $50 \%$ of the private service holders agreed to this statement.

It is important to bear in mind that the study is undertaken in the context of a developing Asian city within a given sample and therefore may not be applicable to another context. The results do not represent the whole population. As an online questionnaire is used in this study it do not incorporate the views of the people having no access to internet. If that part of the society is included, the results will be more representative for the total area under study. 
The results of this study are significantly relevant to transport planning and policy, particularly in a developing city context. It will also provide a way to make ranking and compare between different components of public transportation system of a city. This study results will assist the transportation planners to identify the factors that will motivate the private car users to use public transport and in which sectors of public transport the resource allocation would have the highest positive impact. For planners in future, this study will assist to identify necessities of private car commuters and channelize that as input for sustainable transportation planning.

\section{References}

Andaleeb, S.S.; Haq, M.; Ahmed, R.I. 2007. Reforming intercity bus transportation in a developing country: a passenger driven model, Journal of Public Transportation 10(1): 1-25.

Anik, M.A.H.; Shafquat, K.; Moinul, H. 2017. Social Media and Crowd Sourcing to Evaluate and Compare Priorities and Preferences for Sustainable Transportation System, In Proceedings of the $1^{\text {st }}$ International Conference on Engineering Research and Practice (ICERP), 7-12.

Fang, K. 2014. Can We Build Dhaka out of Traffic Congestion. Available from internet: <http://blogs. worldbank.org $>$.

Friman, M.; Fellesson, M. 2009. Service supply and customer satisfaction in public transportation: The quality paradox, Journal of Public Transportation 12(4): 57-69.

Fujii, S.; Kitamura, R.K. 2003. What Does a One-Month Free Bus Ticket do to Habitual Drivers? An Experimental Analysis of Habit and Attitude Change, Transportation 30(1): 81-95.
Gärling, T.; Eek, D.; Loukopoulos, P.; Fujii, S.; Johansson-Stenman, O.; Kitamura, R.; Pendyala, R.; Vilhelmson, B. 2002. A conceptual analysis of the impact of travel demand management on private car use, Transport Policy 9(1): 59-70.

Hagman, O. 2003. Mobilizing meanings of mobility: car users' constructions of the goods and the bads of car use, Transportation Research Part D: Transport and Environment 8(1): 1-9.

Hensher, D.A.; Stopher, P.; Bullock P. 2003. Service quality-developing a service quality index in the provision of commercial bus contract, Transportation Research Part A: Policy and Practice 37(6): 499-517.

Karim, M.M.; Komori, Y.; Esaki, T.; Ahammed, S. 1998. Mass Transit and Appropriate Measures in Dhaka Metropolitan, In Proceedings of 91st Annual Meeting of AઐWMA, San Diego, California, 14-18.

Kingham, S.; Dickinson, J.; Copsey, S. 2001. Travelling to Work: will People Move out of their Cars, Transport Policy 8(2): 151-160.

Lance, C.E.; Butts, M.M.; Michels, L.C. 2006. The sources of four commonly reported cutoff criteria: What did they really say?, Organizational research methods 9(2): 202-220.

Litan, M.2017. Presentation on research proposal on traffic jam in Dhaka city, Education purpose Research Proposal. Available from internet: <https://www. slideshare.net/MdLitanMia1/presentation-on-researchproposal-on-traffic-jam-in-dhaka-city-by-md-litanmia-jkkniu>.

Lomborg, B. 2016. Daily Star :The smartest ways to deal with traffic congestion in Dhaka. Available from internet: <http://www.thedailystar.net/op-ed/ politics/the-smartest-ways-deal-traffic-congestiondhaka-1220956>. 
Mackett, R.L.; Edwards, M. 1998. The Impact of New Public Transport Systems: Will the Expectations Be Met?, Transportation Research Part A: Policy and Practice 32: 231-245.

Nunnally, J.C. 1978. Psychometric theory (2nd ed.). McGraw-Hill. New York. USA. 701 p.

Ory, D.T.; Mokhtarian, P.L.; Redmond, L.S.; Salomon, I.; Collantes, G.O.; Choo, S. 2004. When Is Commuting Desirable To The Individual?, Growth And Change 35(3): 334-359.

Revised Strategic Transport Plan (RSTP). 2016. Dhaka Transport Co-ordination Authority (DTCA).

Steg L.; Geurs, K.; Ras, M. 2002. The effects of motivational factors on car use: A multidisciplinary modeling approach, Transportation Research A 35(9): 789-806.

Steg, L. 2003. Can Public Transport Compete with the Private Car ?, International Association of Traffic and Safety Sciences 27(2): 27-35.
Stradling, S.G.; Meadows, M.L.; Beatty, S. 2000. Helping Drivers Out of their Cars. Integrating Transport Policy and Social Psychology for Sustainable Change, Transport Policy 7(3): 207-215.

Strategic Transport Plan for Dhaka. 2005. Louis Berger Group and Bangladesh Consultant Ltd. 42 p.

UCLA: Statistical Consulting Group. 2016. Available from internet: <https://stats.idre.ucla.edu/sas/modules/ sas-learning-moduleintroduction-to-the-features-ofsas/ $>$.

Wang, L.; Li, L.; Wu, B.; Bai, Y. 2013. Private Car Switched to Public Transit by Commuters, in Shanghai, China, Procedia-Social and Behavioral Sciences, 96: 12931303.

World population. 2017. Dhaka Population. Available from internet: <http://worldpopulationreview.com/ world-cities/dhaka-population/>. 